\title{
Articles
}

\section{CYCLICALITY OF THE BANKING SECTOR PERFORMANCE AND MACRO ENVIRONMENT IN THE CZECH REPUBLIC, SLOVAKIA AND SLOVENIA}

\author{
Mejra Festić, Dejan Romih*
}

\begin{abstract}
:
An exposure to macroeconomic risk factors across banks is a source of systemic risk that influences the banking sector performance. In this paper, we present some evidence on macroeconomic variables affecting the non-performing loans (NPL) ratio in the Czech Republic, Slovakia and Slovenia.

The GDP growth might have improved borrowers' ability to serve their bank loans in Slovenia, meanwhile the accelerating NPL ratio dynamics has failed to support the hypothesis that the GDP growth fosters an improvement in the NPL ratio in the case of Slovakia. Meanwhile deceleration in the NPL ratio on export impulses has supported a procyclical theory in the Czech Republic, Slovakia and Slovenia. The response of non-performing loans to inflation supports the hypothesis about the lowering inflation that decelerates the NPL ratio. Savings have accelerated the NPL ratio in the case of Slovakia and Slovenia. The banking sector performance is possibly reflecting a favourable assessment of the economic growth and an increasing indebtedness of private sector could become causes of concern if the macroeconomic environment should develop less favourably.
\end{abstract}

Keywords: non-performing loans, macro impulses, cyclicality, economic growth

JEL Classification: F47, G15, G21

\section{Introduction}

The remarkable development in the financial markets over the last few decades has been the prominence of credit and asset price booms, often associated with rapid rates of growth of real fixed investment, export and import, employment growth and rapidly

* Mejra Festić, University of Maribor; Economic Institute of the Law School, Ljubljana (mejra.festic@uni-mb.si; mejra.festic@eipf.si); Dejan Romih, Economic Institute of the Law School, Ljubljana; University of Maribor (dejan.romih@uni-mb.si, dejan.romih@hse.si). 
growth of wages. In the industrial countries, there was a sharp run-up in credit volume and asset prices (particularly equity and real estate) in the early 1970s. A second cycle began in the mid-1980s which turned to a bust in the early 1990s. Examples would include the banking crises in the Nordic countries and Japan in the late 1980s, the Mexican crisis of 1994 and the severe banking problems in East Asia in 1997 and 1998 and the US Great Depression in 1929-1933.

Potential increase in economic growth in the New Member States should evoke higher demand for already growing credits because the catching-up process could be combined with the general banking sectors' procyclicality reinforcing credits growth around the EU accession and second; nominal convergence and lowering of interest rates increase demand for leveraging among companies and boost private consumption (Brzoza-Brzezina 2005). ${ }^{1}$ Bank credits remain an important source of financing for both investment and consumption. Because credit expansion is likely to put upward pressure on banking sector results it is necessary to perceive this effect as stemming from both higher revenues and lower share of non-performing loans (NPL) in total gross loans.

Adequate legal framework improves the NPL performance. Studies suggest as well that fulfillment of convergence criteria and obtaining a stable macro-environment diminish credit risk, which consists of rising dynamics in the NPL ratio. Accordingly, credit expansion and decelerating share of the NPL ratio have proved better results for the banking sector in the Czech Republic, Slovenia and Slovakia in a favourable macroeconomic environment.

Common exposure to macroeconomic risk factors across banks is a source of systemic risk that influences the banking sector results expressed as non-performing loans to total gross loans (NPL) ratio. According to the theory, we expected that GDP growth represents a major challenge to NPL ratio and risk for credit expansion is assumed to be procyclical within the GDP growth. An increasing NPL ratio may be a signal of deterioration banking sector results and of deterioration in the quality of loan portfolio. We analysed the relations between NPL ratio and macroeconomic variables as a source of systemic risk in order to assess the banking sector's vulnerability to bad loans performance on a macroeconomic level. We tested a significance of macroeconomic variables conditioning the NPL ratio and the hypothesis of procyclicality between the real sector performance and the banking sector results in the Czech Republic, Slovakia and Slovenia.

\section{Overview of the Literature on Macro Environment Influencing the NPL Ratio}

The global financial system has been subject to a variety of disruptive incidents reflecting the increasing complexity of modern financial systems. Developments have sharply increased competitive pressures in the financial sector that have led to changes in financial structure, financial stability and financial behaviour. These changes have also implied a marked increase in the variety of credit sources, reductions in the costs of bank-

1 Greece and Portugal doubled lending to GDP ratio between 1995 and 2003 and the non-performing loans ratio has been falling. Brzoza-Brzezina (2005) argues that potential credit boom began 2-3 years before the introduction of euro and most significant increases occurred in the countries with the highest interest rate differential. 
ing services and the intermediation costs of credit and stimulated an increase of incentives to engage in risky behaviour (Rajan 2005).

Measuring (credit) risk includes a wider range of indicators - micro and macro. Complementing financial data and overall macroeconomic data are required in order to assess the current state of cycle (Borio and Lowe 2002). Several recent studies complement broad-based macroindicators with a set of aggregate banking sector variables, such as credits to private sector, deposits, banking sector foreign reserves, institutional indicators, financial liberalization etc., as early warning systems indicators. In addition, macro-prudential analysis involves bank-by-bank stress testing, sectoral analysis and integrated analysis using the value at risk (VaR) framework and other concepts. Measuring the range of possible outcomes can be thought of as having a number of common building blocks, which include: a system of rating loans, assumptions about the correlation of default probabilities across borrowers, assumptions about the loss incurred in the case of default, assumptions regarding the correlation between the default probabilities and loss given default, etc. (Golin 2005).

Banks are confronted with risks regarding economic and institutional environment. The primary risks associated with banking activities are credit risk, liquidity risk, market risk and country risk. It is of the utmost importance to have a sufficient volume of quick assets that correspond to the size of the bank and may be used to cover any unforeseen outflows of funds in order to lower a liquidity risk. Market risk covers interest rate risk, currency risk, equity and commodity risk. The relatively unstable development of share prices on the capital market increases equity risk due to securities falling in value that arises from developments on the capital market. A country risk is linked with the changes, primarily political, legislative as well economic downturn that might prevent clients and business partners in the relevant country from repaying their liabilities. Common exposure to macroeconomic risk factors across banks is a source of systemic risk that influences the quality of the loan portfolio expressed as the non-performing loans to total gross loans (NPL) ratio and an increasing ratio may be a signal of deterioration in the banking sector results.

Arpa et al. (2001) conclude that the share of risk provisions in the total loans of the banking sector varies with real GDP growth, real interest rates, CPI inflation and real estate price inflation. Blaschke and Jones (2001) propose applying the VAR methodology to investigate the transmission from GDP, inflation, money interest rate and the terms of trade to the NPL ratio. Shu (2002) examines the regression analysis that indicates that the NPL ratio rises with increasing nominal interest rates, but decreases with higher CPI inflation, economic growth and property price inflation, exchange rate, the terms of trade and share prices. Quagliariello (2003) presents a regression between the evolution of NPL as the dependent variable and a set of explanatory variables: real GDP growth rate, growth of real gross fixed investment and consumption, change in the unemployment rate, the CPI, the real exchange rate and the M2 growth rate. Babouček and Jančar (2005) investigate economic developments by unemployment, GDP growth, export, import, appreciation, CPI and credits growth as the indicators of the NPL ratio performance.

The list of frequently investigated macro variables includes real GDP, a monetary aggregate, loans to the business sector and households, unemployment rate, the 
consumer price index, real effective exchange rate, nominal exchange rate, the terms of trade, exports, imports, interest rates, investment, savings and the NPL ratio itself. The empirical results found in the selected literature are an important source of the hypothesis for responsiveness of the NPL ratio on macro factors.

Capital inflows could result in an expansion of domestic credits; and a sudden withdrawal of bank deposits leaving domestic banks illiquid might take place after a period of large inflows of foreign short-term capital when domestic interest rates fall, when depreciation is expected or when confidence in the economy wavers, when disruption on financial markets or balance of payments crises is expected (Calvo and Mendoza 2000, Edwards 2001). The worsening of banking sector results mismatch occurs when banks borrow in foreign currency and lend in domestic currency due to an unexpected depreciation of the domestic currency that threatens bank profitability and the NPL performance. Meanwhile, appreciation of real exchange rate could contribute to the build-up of crisis through shifts in international competitiveness coupled with terms of trade deterioration. Limited growth prospects in export-oriented industries could ultimately lead to economic contraction with direct implications on loans performance as the bank lending surveys show that loans granted to enterprises are partly hedged by their export proceeds (Kaminsky and Reinhart 1999).

The effect of falling asset prices/share prices ('wealth effects') in the presence of fixed nominal debt may cause wide-spread default among firms as well as banking distress. Second, if equity prices are overvalued, calculated probability defaults are likely to underestimate the true probabilities of default, and perhaps suggest a relatively low level of credit risk (Borio and Lowe 2002). Applying soft budget constraints prevalent in many transition countries for credits to enterprises may lead to considerable losses in the economy when investments turn out to be counterproductive (Berglöf and Roland 1995).

If the expansion is associated with rapid credit growth, large increases in asset prices, high level of investment, export growth and excessive capital accumulation, the level of credit risk is higher because risk is built up in a boom but materialises in the downturn. The impact of the GDP growth and of the business cycle on credit risk is usually represented as procyclical. Expected unemployment growth rationally decreases demand for loans and in this case rising unemployment improves loan portfolio quality (Borio et al. 2001).

Liberalization increases the costs of funds and nurtures the culture of high-risk behaviour and in order to mitigate risks, higher rates are charged to high-risk borrower further increasing banks' overall exposure. Second, an increase in short-term interest rates (paid on liabilities) forces banks to increase the interest rate paid to depositors, but because the asset side of bank balance sheets usually consists of loans of longer maturity at fixed interest rates, banks cannot increase their lending rates quickly enough and they must bear losses because of maturity transformation (Rajan 2005). Further, when inflation is drastically reduced, banks see one of their main sources of revenue disappear and stabilization from chronic inflation may lead to a reduction in the size of the banking system which adversely affects the economy (English 1996).

The savings surplus allows moving toward capital account convertibility, thereby further reducing the risk of potential bank crisis. Second, it can be argued that growth in the amount of available finance may precipitate financial crises and harm economic 
development due to soft budget constraints. Third, low banks' capitalization often leads to the adoption of imprudent lending strategies with direct implications for banks' loans portfolios, which tend to be heavily skewed toward high-risk projects (Eichengreen et al. 1999, Lardy 1999).

\section{Macro Environment and the Banking Sector in the Czech Republic, Slovakia and Slovenia}

The New Member States have made a great progress in terms of nominal convergence as average inflation fell and GDP growth has lead to improvement in fiscal deficits according to the government's fiscal consolidation plans. Despite that a substantial progress has been made in reducing inflation (Table 1), inflation reaccelerated later again due to indirect taxes and administrative prices, higher prices of food and impact of increasing fuel prices. A considerable progress has been made in real convergence as well. The productivity increases in the tradeable sector induced effects to the overall inflation differences in catching-up economies. Economic growth has been relatively high and it is broadly based: domestic demand has been an important factor of growth that was boosted by a from abroad financed boom of bank lending and real wage growth on the back of productivity gains as well as by exports.

Catching-up economies have financed a part of their investment through foreign direct investment and the huge current account deficits have been financed by a steady increase of net-inflows of foreign direct investment, net portfolio investment and net foreign currency loans (Breuss et al. 2004). The positive impact of foreign direct investment and import of capital goods on economic growth is visible in the diversification of foreign trade structure, the increase of labour productivity and the improvement of competitiveness of the export industries, showing high growth rates, the Balassa-Samuelson-effect and improvement in the market structure (Brandmeier 2006, pp. 396-400, Havlik 2003). Higher investment may lead to a rise in external competitiveness and following higher export growth expands the capability of a country to service foreign debt.

Uncertainty about economic and financial developments has been reflected in higher interest rate differentials. The catching-up economies that have been faced with relatively high interest rates needed to cope with increasing level of foreign currency loans stimulated by the financial liberalization; and the persisting interest rate differentials put appreciating pressure on domestic currencies.

Capital markets are not very well developed, stock market capitalization is relatively low and the private sector relies more on bank finance than on stock market financing. Credit growth to the corporate sector has lagged behind loans to households (this can be partly explained by the fact that a share of investment by the non-financial corporate sector has been financed by retained earnings, foreign capital - including credits from banks in other countries - and foreign direct investment).

The structure of banking sector is dominated by commercial banks and customer deposits are important funding source for banks. Removal of barriers, increasing competitiveness, the possibility of banks to engage in a wider range of financial activities and a positive association between foreign ownership and banking sector performance show the trend of catching-up with BIS standards. Significant progress has 
been made in supervision and insolvencies procedure. The EBRD indicators show that the capacity for effective prudential regulation and supervision have been developed; and banks surveyed identified consolidation, adaptation of the organizational structure and regulatory incentives as significant drivers of change. Banks have benefited from an enhancing of asset quality and they improved RoA/RoE ratios (Table 1). The main drivers of the boosting profitability were the growth of lending as well as the rise in fees, commission income; profits were also supported by continued cost-containment and by a further decrease in impairment charges.

Table 1

Convergence Criteria and Banking Sector Indicators in the Czech Republic, Slovakia and Slovenia in 2006

\begin{tabular}{|l|c|c|c|c|l|}
\hline & $\begin{array}{c}\text { Public debt } \\
\text { (in \% GDP) }\end{array}$ & $\begin{array}{c}\text { Fiscal deficit } \\
\text { (in \% GDP) }\end{array}$ & Inflation a & $\begin{array}{c}\text { (Long-term) } \\
\text { interest rate } \\
\text { (2005, in \%) }\end{array}$ & Exchange rate regime \\
\hline $\begin{array}{l}\text { Reference } \\
\text { value }\end{array}$ & 60.0 & -3.0 & 2.0 & 3.0 & \\
\hline CZ & 36.6 & -3.7 & 2.9 & 3.5 & Managed float (EUR) \\
\hline S & 38.2 & -3.0 & 3.6 & 3.5 & ERM II since Nov. 2005 \\
\hline SLO & 29.5 & -1.9 & 2.5 & 3.8 & $\begin{array}{l}\text { ERM II since June 2004 and the } \\
\text { Euro zone from the Jan. 2007 }\end{array}$ \\
\hline
\end{tabular}

\begin{tabular}{|l|c|c|c|c|c|c|c|c|}
\hline & $\begin{array}{c}\text { Rating } \\
\text { Moody's / } \\
\text { Fitch and } \\
\text { Standard } \\
\text { and Poor's }\end{array}$ & $\begin{array}{c}\text { Asset } \\
\text { quality } \\
\text { (NPL as \% } \\
\text { of total } \\
\text { loans) }\end{array}$ & $\begin{array}{c}\text { Capital } \\
\text { adequa- } \\
\text { cy }^{\mathbf{d}}\end{array}$ & $\begin{array}{c}\text { Stock market } \\
\text { capitalization } \\
\text { (\% of GDP) }\end{array}$ & $\begin{array}{c}\text { EBRD } \\
\text { index of } \\
\text { banking } \\
\text { sector } \\
\text { reform }^{\text {f }}\end{array}$ & $\begin{array}{c}\text { Foreign } \\
\text { currency } \\
\text { loans to } \\
\text { total loans } \\
\text { ratio (\%) } \\
\mathbf{2 0 0 5}\end{array}$ & $\begin{array}{c}\text { Foreign } \\
\text { banks (\%) }\end{array}$ & $\begin{array}{c}\text { RoA/ } \\
\text { RoE (\%) } \\
\mathbf{2 0 0 5}\end{array}$ \\
\hline CZ & A1/A- & 4.3 & 11.9 & 32 & 4.0 & 11 & 96 & $1.4 / 25.3$ \\
\hline S & A3/A- & 2.0 & 15.9 & 10 & 3.3 & 28 & 96 & $0.9 / 10.0$ \\
\hline SLO & Aa3/AA- & 4.9 & $11.8 *$ & 23 & 3.3 & $37 *$ & 36 & $1.0 / 13.8$ \\
\hline
\end{tabular}

${ }^{a}$ consumer prices \% y-o-y, ann. avg.; ${ }^{b}$ country rating (foreign currency - long run) for December $2004 ;{ }^{c}$ assets are defined as non-performing loans if the obligor has failed for bankruptcy and doubtful assets are defined as all other irrevocable commitments that could give rise to risk; definitions of non-performing loans and other doubtful loans differ between countries, data for 2005; ${ }^{d}$ solvency ratio; ${ }^{e} 2004 .{ }^{f}$ The ERBD (European Bank for Reconstruction and Development) indicators of banking sector reform are measured on the scale from 1 to $4+$ : score 1: underdeveloped financial sector; score 2: established internal currency convertibility, significant liberalised interest rates and credit allocation; score 3: achieved substantial progress in establishing prudential regulation and supervision framework; score 4: level of reform approximates the BIS institutional standards (2004); ${ }^{\mathrm{g}}$ asset share of foreign banks/states' share in \% (2004); ${ }^{\mathrm{h}}$ return on assets, return on equity (after tax in \% of average assets).

* Symbols: CZ: the Czech Republic, S: Slovakia, SLO: Slovenia.

Source: European Commission (2006), EU Monitor (2006, 10), IMF (2006), ECB (2006).

While banks' risk management systems have improved over recent years (foreign ownership has contributed to an improvement of risk profile and transfer of technology), there are some uncertainties about the ways in which risks have been redistributed by credit risk transfer products, both within the banking system and between banks and other financial institutions, and about how the market for these products would perform in a more challenging macro-financial environment. While 
favourable macroeconomic environment has generally been conducive to banking sector stability, some problem areas remain where further improvements are needed regarding the improvements of the legal environment, engaging in a wider range of financial activities and the level of financial intermediation.

The increasing role of foreign-owned banks contributed to bolster the development of the Czech banking sector and their activities broadened only after strategic foreign investors became majority owners of formerly state-owned banks (Bárta and Singer 2006). Between 1995 and 2000, the composition of banks' assets developed more towards "safer" assets, such as deposits with the Czech National Bank. There has been an improvement in the quality of the balance sheet of the surviving banks as low-quality credits have been taken off banks' balance sheets and passed on to the Konsolidační banka or sold at a discount to other banks. ${ }^{2}$ After 2002, the Czech banking system benefited substantially from the strong GDP growth. In the Czech Republic, banks' balance tends to be excessively liquid and a sharp reduction in total lending in 2002 contributed to the NPL ratio lowering.

The economic environment favourably influenced the Slovak banking sector after 2000. This applies both to external factors, such as growth in the global economy and continuing positive development in banking groups across the EU, and to domestic factors, in particular the Slovak Republic's macro-economic development (SNB 2004). Banks compensated for the decline in interest rates in their asset operations through an increased volume of lending to households. The significant growth in household lending led also to an increase of the NPL. The efforts of several banks, in particular those having incurred a high share of NPL towards businesses in the past years, were directed at the recovery of corporate loan portfolios. This resulted in a fall in the volume of NPL in Slovakia. In 2004, the Slovak banking sector reported relatively high capital adequacy, which created a basis for growth in risk-weighted assets. Slovak banking sector was almost completely privatized and total assets of banking sector are comparable in size with Slovenia.

In Slovenia, the consolidation in the banking sector and the relatively high level of concentration are primarily due to mergers between domestic banks in order to achieve a critical mass and to remain competitive. Slovenia has a high share of state owned banks and it has had high net interest margins in the CEE economies with the solvency ratio close to the average of West European banks. Despite the fact that lending was growing rapidly, banks maintained adequate solvency buffers. A change in Slovenian accounting rules at the start of 2002, due to the abolition of certain revaluation methods, had a positive net effect on the profit. In March 2002, the Slovenian Banking Act of 1999 was amended and now includes capital adequacy guidelines for banks and savings institutions. Generally, a stable economy and a better lending policy have improved the quality of assets. While favourable macroeconomic environment has generally been conducive to banking sector stability (Festić 2007), some areas remain where further changes are needed regarding the improvements of the legal environment, engaging in a wider range of financial activities and the level of financial intermediation.

2 It should also be emphasized, that according to CNB methodology, "watch" credits are included in the category of classified credits. This is not common in many countries. The sum of the three high-risk categories consists of "sub-standard", "doubtful" and "loss" credits. 


\section{Empirical Analysis}

The monthly time series expressed as growth rates were used for the period from January 1995 to December 2006 for the explanation of the NPL ratio in Slovakia, Slovenia and the Czech Republic. ${ }^{3}$ On the basis of covariance matrix and contribution of eigenvalues to the explained variance we have chosen the time series, which have maximal explanation level of the NPL ratio and which explain the residual factors of endogenous variable movements (NPL) (Kavkler and Böhm 2006). We excluded the strongly correlated time series (Wall et al. 2003, see Appendix Table A) and decided to use the following time series for explanation of NPL movements: time series of short-run (6-months lending) real interest rate, real gross domestic product, export of goods and services, real savings of private sector with banks, harmonized consumer price index, real investment (as gross capital formation in share of GDP) and real effective exchange rate for Slovakia and Slovenia; for the Czech Republic we have chosen time series of long-run (5-year lending) real interest rate, export of goods and services, unemployment rate, harmonized consumer price index, real investment (as gross capital formation in share of GDP), stock exchange index and real effective exchange rate.

Table 2

Results of the Augmented Dickey-Fuller Test for the Czech Republic, Slovakia and Slovenia

\begin{tabular}{|l|c|c|c|c|c|c|}
\hline Variable & \multicolumn{2}{|c|}{ Czech Republic } & \multicolumn{2}{c|}{ Slovakia } & \multicolumn{2}{c|}{ Slovenia } \\
\hline & Level & First diff. & Level & First diff. & Level & First diff. \\
\hline REFFEXCHR & -2.649812 & -12.12118 & -0.226498 & -9.665381 & -2.883076 & -11.80905 \\
\hline GDP & -1.215898 & -4.33196 & -1.560554 & -8.31674 & -1.993530 & -3.700409 \\
\hline EXP & -1.789807 & -4.986233 & -1.143570 & -11.59260 & -1.824939 & -9.784243 \\
\hline UNEMPLOY & -2.036084 & -3.987668 & -1.219073 & -7.36399 & -2.078444 & -3.889008 \\
\hline INCPI & -1.935327 & -3.925350 & -2.089532 & -3.833222 & -0.458765 & -3.644830 \\
\hline SAVINGS & -2.012276 & -4.524543 & -2.107762 & -8.793177 & -1.714055 & -16.86599 \\
\hline INTRLR & -1.065934 & -3.602296 & -2.504406 & -12.37141 & -1.470219 & -3.546875 \\
\hline INTR3M & -2.030208 & -13.70345 & -1.685119 & -14.80404 & -2.874139 & -8.299430 \\
\hline SHARES & -1.746367 & -8.949441 & -1.002380 & -10.36908 & -1.743364 & -9.040177 \\
\hline EXCHR & -3.666615 & -11.23871 & -1.216345 & -13.21983 & -1.068146 & -5.028452 \\
\hline PDEBT & -0.023002 & -11.00756 & -2.011245 & -9.062234 & -3.321695 & -15.83194 \\
\hline NPL & -2.553890 & -12.32520 & -0.962504 & -10.77835 & -1.722136 & -11.56742 \\
\hline Cricalvalest & -1.260577 & -6.32721 & -1.792462 & -3.789077 & -5.390285 & -3.642469 \\
\hline
\end{tabular}

Critical values at $1 \%, 5 \%$ and $10 \%$ level of significance $-3.473096,-2.880211$ and -2.576805

Source: Own calculations (March 2007).

Stationarity of the used time series has been obtained by the first order difference (Table 2) and accepted at 1\% significance level (Dickey and Fuller 1979, pp. 427-431).

3 The Eviews 4.1 programme was used, employing the EIPF (Economic Institute of the Law School, Ljubljana), Baca (Bank Austria Creditanstalt-Unicredit Group) internal data base and central banks internal data base. For GDP and unemployment we have interpolated quarterly data into monthly data. We used constant interpolation method (constant with average matched to the source data) for quarterly data into monthly data. 
The time series were normalized by average value and standard deviation. The residual serial correlation (Breusch-Godfrey, ARCH) LM Test was used for a homoskedasticity of residuals estimation (Tables 3-5), testing the null hypothesis that there is no serial correlation in the residuals.

In our work we relied on the ordinary least squares, variance decomposition and impulse response methodology. The lag length selection in the models specified was based on the Akaike information criterion and the Schwarz information criterion. The ARMA technique incorporates the residual from the past observation into the regression model for the current observation, the correlogram has shown that a serial correlation dies off after a small number of lags/increasing number of lags, the series obey a low order moving average process/autoregressive process (MA/AR) (Box and Jenkins 1976). According the Chow forecast used for proving the stability of estimated OLS functions we have accepted the hypothesis of structural stability (Thursby 1982, pp. 314-321).

The VAR models include a considerable number of variables and it is necessary to test each of them for exogeneity. The testing for exogeneity follows the methodology proposed by Greene (2003). Greene (2003, p. 582) clarifies that the tests for exogeneity can be based on the concept of Granger causality applied to individual equations and examined by the Wald test in order to test the significance of particular explanatory variable. The reaction of a variable to an impulse generated by another variable is assumed to reveal the causal relationship between them (Engle and Granger 1978) and the relative importance of each random innovation in affecting the variables in the VAR model.

Macroeconomic shocks affecting the NPL ratio growth are analysed by impulse responses (Sims and Zha 1999). Analysing the residuals' covariance matrix facilitates assessment of the robustness of the impulse analysis to re-ordering of variables. Analysis of the residuals shows that the results of the VAR estimations suggest that the model is correctly specified, but at the same time indicates that some of the estimations may be inefficient and that there may be correlations in the model's covariance matrix. Since there are correlations between some residuals, it is necessary to examine the sensitivity of the responses to re-ordering of the variables and in this context identification problem is related to VAR methodology. Recursive identification, which separates the residuals into orthogonal shocks using Cholesky factorisation of the covariance matrix of residuals, is the standard way to meet these requirements (Canova 2003). Cholesky uses the inverse of the Cholesky factor of the residual covariance matrix ordering to orthogonalize the impulses. Recursive identification attributes all the contemporaneous correlations of the residuals and all of the effect of any common component to the variable that is ordered first in the VAR system. Each impulse or shock equals one standard deviation of the time series of the respective variable and causes other time series to respond (Pesaran and Shin 1998).

\subsection{Empirical Results}

Macroeconomic shocks affecting the NPL ratio are analysed by OLS and impulse response innovations to the NPL ratio explained by real effective exchange rate, unemployment rate, real gross domestic product, export, long/short-run (real) interest rate, harmonized consumer price index, stock exchange index, investment (as a share of GDP) and real saving of private sector with banks. 
Table 3

OLS Results for the Czech Republic

\begin{tabular}{|c|c|c|c|}
\hline \multicolumn{4}{|c|}{ Dependent variable: NPL. Sample (adjusted): 1995:01 2006:12, (Included observations: 144) } \\
\hline Variable & Coefficient & Std. Error & t-Statistic (Prob.) \\
\hline $\operatorname{EXP}_{(-10)}$ & -0.231658 & 0.096659 & $-2.396656(0.0019)$ \\
\hline $\operatorname{INVEST}_{(-8)}$ & -0.237313 & 0.066261 & $-3.581510(0.0005)$ \\
\hline UNEMPLOY $_{(-4)}$ & -0.178075 & 0.086329 & $-9.043840(0.0037)$ \\
\hline HCPI & -0.156245 & 0.056843 & $-2.748710(0.0068)$ \\
\hline SHARES $_{(-2)}$ & -0.137602 & 0.056879 & $-2.770812(0.0064)$ \\
\hline REFFEXCHR & -0.129152 & 0.108578 & $-5.189481(0.0023)$ \\
\hline $\operatorname{INTRLR}_{(-12)}$ & -0.386190 & 0.094475 & $-17.84798(0.0000)$ \\
\hline $\mathrm{MA}(1)$ & 0.759045 & 0.058135 & $13.05653(0.0000)$ \\
\hline \multicolumn{4}{|c|}{$\begin{array}{l}\mathrm{R}^{2}=0.8631, \mathrm{~S} . \mathrm{E} .=0.1539, \mathrm{SSR}=0.2953, \mathrm{AIC}=-2.8199, \mathrm{DW}=1.9162 \\
\mathrm{LM}_{(2)}=1.782545(0.594261), \mathrm{LM}_{(4)}=0.527194(0.7423144), \mathrm{LM}_{(8)}=0.435878(0.827451) \\
\text { Chow forecast test }(1998: 01-2006: 01)=0.687594(0.775654) \\
\text { The Breusch-Godfrey serial correlation LM test for the null hypothesis of no serial correlation in the } \\
\text { residuals up to order } \mathrm{p} \text { (with } \mathrm{p}=2,4,8) \text { are given above. The p-values are stated in brackets. } \\
\text { Chow forecast test for the null hypothesis of no structural change in the estimated function. }\end{array}$} \\
\hline
\end{tabular}

Source: Own calculations (March 2007).

If investment activity growth rate in the Czech Republic has risen by $1 \%$ point, while other predictors have been held constant, then the NPL ratio growth rate has decelerated by $0.23 \%$ point. The variable real effective exchange rate growth with the regression coefficient of -0.13 has had a decelerating effect on the NPL ratio growth. Increase in export growth rate by $1 \%$ point has decelerated the NPL ratio growth by $0.23 \%$ point. The response of the dependent variable on the long-run (lending) interest rate growth has been decelerating with regression coefficient of -0.38 , respectively. An increase in unemployment growth has decelerated the NPL ratio growth by $0.18 \%$ point.

Table 4

\section{OLS Results for Slovakia}

Dependent variable: NPL. Sample (adjusted): 1995:01 2006:12, (Included observations: 144)

\begin{tabular}{|l|c|c|c|}
\hline Variable & Coefficient & Std. Error & t-Statistic (Prob.) \\
\hline GDP $_{(-11)}$ & 0.200491 & 0.083291 & $2.407125(0.0174)$ \\
\hline INVEST $_{(-7)}$ & -0.526961 & 0.078432 & $-6.718698(0.0000)$ \\
\hline EXP $_{(-5)}$ & -0.180821 & 0.038153 & $-2.118305(0.0259)$ \\
\hline SAVINGS $_{(-12)}$ & 1.632555 & 0.141258 & $4.783936(0.0000)$ \\
\hline REFFEXCHR & -0.306488 & 0.122503 & $-2.501888(0.0135)$ \\
\hline INTR3M & -0.449279 & 0.071924 & $-7.636928(0.0000)$ \\
\hline HCPI $_{(-4)}$ & -0.494764 & 0.089184 & $-5.547693(0.0000)$ \\
\hline MA(1) $^{2}$ & 0.997442 & 0.025493 & $39.12682(0.0000)$ \\
\hline
\end{tabular}

$\mathrm{R}^{2}=0.8775$, S.E. $=0.1572, \mathrm{SSR}=0.4129, \mathrm{AIC}=-2.8088, \mathrm{DW}=1.6361$

$\mathrm{LM}_{(2)}=2.458745(0.365897), \mathrm{LM}_{(4)}=0.944587(0.653758), \mathrm{LM}_{(8)}=0.548569(0.785412)$

Chow forecast test $(1997: 01-2005: 06)=0.936102(0.665485)$

The Breusch-Godfrey serial correlation LM test for the null hypothesis of no serial correlation in the residuals up to order $\mathrm{p}$ (with $\mathrm{p}=2,4,8$ ) are given above. The $\mathrm{p}$-values are stated in brackets.

Chow forecast test for the null hypothesis of no structural change in the estimated function.

Source: Own calculations (March 2007). 
In Slovakia, an increase of GDP growth by $1 \%$ point has accelerated the NPL ratio growth rate by $0.20 \%$ point. An increase in savings growth by $1 \%$ point (ceteris paribus) has accelerated the NPL ratio growth by $1.63 \%$ point. The regression coefficients of interest rate growth, real effective exchange rate growth, inflation and investment growth have decelerated the NPL ratio growth. The regression coefficient of export growth indicates a relatively negligent decelerating influence on the NPL ratio growth. We have proved that in our empirical investigation for Slovakia, the variables that have deteriorated (i.e. increase) the NPL growth rate are savings and GDP growth.

Table 5

OLS Results for Slovenia

\begin{tabular}{|c|c|c|c|}
\hline \multicolumn{4}{|c|}{ Dependent variable: NPL. Sample (adjusted): 1995:01 2006:12, (Included observations: 144) } \\
\hline Variable & Coefficient & Std. Error & t-Statistic (Prob.) \\
\hline $\mathrm{GDP}_{(-6)}$ & -1.124252 & 0.059367 & $-18.93744(0.0000)$ \\
\hline INVEST & -0.682189 & 0.004274 & $-4.519050(0.0064)$ \\
\hline $\mathrm{EXP}_{(-14)}$ & -0.497045 & 0.020532 & $-8.456613(0.0014)$ \\
\hline SAVINGS $_{(-5)}$ & 1.759906 & 0.095865 & $19.80176(0.0000)$ \\
\hline REFFEXCHR & -0.786193 & 0.031420 & $-3.214377(0.0028)$ \\
\hline 96696 INTR3M & 0.295733 & 0.031242 & $12.66656(0.0000)$ \\
\hline $\mathrm{HCPI}_{(-3)}$ & -0.082564 & 0.026491 & $-7.116642(0.0022)$ \\
\hline $\mathrm{MA}(1)$ & 0.850431 & 0.054824 & $15.51200(0.0000)$ \\
\hline $\begin{array}{l}\mathrm{R}^{2}=0.8824, \mathrm{~S} . \mathrm{E} \\
\mathrm{LM}_{(2)}=2.874694 \\
\text { Chow forecast te } \\
\text { The ARCH seria } \\
\text { to order } \mathrm{p} \text { (with } \mathrm{p} \\
\text { Chow forecast te }\end{array}$ & $\begin{array}{l}\mathrm{R}=0.4995, \mathrm{~A} \\
\mathrm{M}_{(4)}=1.6841 \\
05: 10)=0.75 \\
\mathrm{M} \text { test for the } \\
\text { given above. } \\
\text { lypothesis of }\end{array}$ & $\begin{array}{l}7, \mathrm{DW}=1.7 \\
5), \mathrm{LM}_{(8)}=0 \\
458) \\
\text { esis of no ser } \\
\mathrm{S} \text { are stated ir } \\
\text { change in th }\end{array}$ & $\begin{array}{l}(0.815942) \\
\text { ation in the residuals up } \\
\text { ed function. }\end{array}$ \\
\hline
\end{tabular}

Source: Own calculations (March 2007).

In Slovenia, faster GDP growth, export and investment growth have slowed down the growth of the NPL ratio. An increase in savings growth by $1 \%$ point (ceteris paribus) has increased the NPL ratio growth by $1.76 \%$ point. An increase in (short-run) interest rate growth by $1 \%$ point has accelerated the NPL ratio growth by $0.29 \%$ point. The variables real effective exchange rate and inflation with the regression coefficients of -0.78 and -0.08 , respectively, have also decelerated the NPL ratio growth. 
Table 6

Variance Decomposition of NPL

CZECH REPUBLIC ${ }^{\mathrm{A}}$

\begin{tabular}{|l|c|c|c|c|c|c|c|c|}
\hline Period & EXP & INVEST & UNEMPLOY & HCPI & SHARES & REFFEXCHR & INTRLR & NPL \\
\hline 12 & 22.364761 & 19.03202 & 10.48460 & 15.11050 & 6.790184 & 12.99594 & 12.131083 & 1.09091 \\
\hline 24 & 23.686008 & 18.26808 & 10.92141 & 17.16278 & 6.127316 & 10.88154 & 11.101971 & 1.85089 \\
\hline 36 & 24.311757 & 17.32476 & 11.84252 & 16.68348 & 6.211931 & 10.56171 & 11.090495 & 1.97334 \\
\hline
\end{tabular}

SLOVAKIA $^{B}$

\begin{tabular}{|l|c|c|c|c|c|c|c|c|}
\hline Period & GDP & INVEST & EXP & SAVINGS & REFFEXCHR & INTR3M & HCPI & NPL \\
\hline 12 & 11.47828 & 19.02885 & 16.252420 & 10.50054 & 12.70319 & 10.79599 & 16.99399 & 2.24672 \\
\hline 24 & 12.07423 & 18.88824 & 16.396213 & 11.07735 & 13.88526 & 10.93327 & 14.46529 & 2.28012 \\
\hline 36 & 12.92613 & 18.10371 & 16.428072 & 11.09301 & 12.92505 & 10.92047 & 14.90036 & 2.70318 \\
\hline
\end{tabular}

SLOVENIA $^{\mathrm{C}}$

\begin{tabular}{|l|c|c|c|c|c|c|c|c|}
\hline Period & GDP & INVEST & EXP & SAVINGS & REFFEXCHR & INTR3M & HCPI & NPL \\
\hline 12 & 18.78385 & 12.62355 & 18.530707 & 21.76431 & 10.15587 & 10.03519 & 6.814659 & 1.29187 \\
\hline 24 & 19.63831 & 14.57976 & 14.681634 & 23.61786 & 10.09172 & 10.03273 & 5.668246 & 1.68971 \\
\hline 36 & 19.88433 & 14.56296 & 14.708619 & 23.90075 & 10.06850 & 10.04086 & 4.959236 & 1.87474 \\
\hline
\end{tabular}

${ }^{A}$ Variance decomposition of NPL for the CZECH REPUBLIC from January 1995 to December 2006: lag 1-3 months for endogenous variable.

Cholesky Ordering: export, investment, unemployment, HCPI, shares, real effective exchange rate, long-run interest rate, NPL.

${ }^{B}$ Variance decomposition of NPL for SLOVAKIA from January 1995 to December 2006: lag 1-4 months for endogenous variable.

Cholesky Ordering: GDP, investment, export, savings, real effective exchange rate, short-run interest rate, inflation, NPL.

${ }^{C}$ Variance decomposition of NPL for SLOVENIA from January 1995 to December 2006: lag 1-3 months for endogenous variable.

Cholesky Ordering: GDP, investment, export, savings, real effective exchange rate, short-run interest rate, inflation, NPL.

Source: Own calculations (March 2007).

In the Czech Republic, shocks to export account for about $24 \%$ of the NPL variance decomposition; shocks to investment account for about $17 \%$ of the NPL variance decomposition; meanwhile shocks to inflation account for about $16 \%$ of the NPL variance decomposition; shocks to real effective exchange rate, unemployment and long run interest rate account for about $11 \%$ of the NPL variance decomposition in the time period of 36-month.

In Slovakia, shocks to export and investment account for about $16-18 \%$ of the NPL variance decomposition; shocks to real effective exchange rate and GDP account for about $12 \%$ of the NPL variance decomposition; shocks to savings and interest rate account for about $11 \%$ of the NPL variance decomposition in the time period of 36-month.

In Slovenia, shocks to savings account for about $23 \%$ of the NPL variance decomposition; shocks to GDP account for about $20 \%$ of the NPL variance decomposition; meanwhile shocks to export and investment account for about $15 \%$; shocks to real effective exchange rate and interest rate account for about $10 \%$ of the NPL variance decomposition (Table 6). 
Table 7

Impulse Analysis Results to NPL

CZECH REPUBLIC

\begin{tabular}{|l|c|c|c|c|c|c|c|c|}
\hline Period & EXP & INVEST & UNEMPLOY & HCPI & SHARES & REFFEXCHR & INTRLR & NPL \\
\hline 12 & -0.01241 & -0.05541 & -0.00587 & -0.00602 & -0.00308 & -0.01687 & -0.01075 & 0.00025 \\
\hline 24 & -0.07874 & -0.06584 & -0.00634 & -0.00787 & -0.00321 & -0.00547 & -0.00897 & 0.00018 \\
\hline 36 & -0.05422 & -0.04587 & -0.00547 & -0.00621 & -0.00398 & -0.01235 & -0.01387 & 0.00008 \\
\hline
\end{tabular}

SLOVAKIA

\begin{tabular}{|l|c|c|c|c|c|c|c|c|}
\hline Period & GDP & INVEST & EXP & SAVINGS & REFFEXCHR & INTR3M & HCPI & NPL \\
\hline 12 & 0.00698 & -0.00398 & -0.01202 & -0.00658 & -0.01048 & -0.01799 & 0.00758 & 0.00012 \\
\hline 24 & 0.01578 & -0.02054 & -0.00987 & 0.00012 & -0.00928 & -0.00879 & -0.01987 & 0.00058 \\
\hline 36 & 0.01499 & -0.00687 & -0.01325 & 0.00234 & -0.01987 & -0.01658 & -0.01778 & 0.00005 \\
\hline
\end{tabular}

SLOVENIA

\begin{tabular}{|l|c|c|c|c|c|c|c|c|}
\hline Period & GDP & INVEST & EXP & SAVINGS & REFFEXCHR & INTR3M & HCPI & NPL \\
\hline 12 & -0.01897 & -0.00403 & -0.00054 & 0.03874 & -0.00106 & 0.00049 & -0.00984 & 0.00003 \\
\hline 24 & -0.01265 & -0.00368 & -0.00406 & 0.03036 & -0.00023 & 0.00098 & -0.00626 & 0.00006 \\
\hline 36 & -0.02012 & -0.01094 & -0.00397 & 0.03978 & -0.00183 & 0.00164 & -0.00798 & 0.00004 \\
\hline
\end{tabular}

Accumulated response of NPL to Cholesky d. f. adjusted 1 St. dev. Innovations, Standard Errors: Analytic. Impulse response analysis - innovations to NPL from January 1995 to December 2006.

Source: Own calculations (March 2007).

In the Czech Republic investment, unemployment, export and interest rate have decelerated the NPL ratio in the time period of 24 to 36-month; the NPL ratio responses on real effective exchange rate, share prices and inflation have been slightly decelerating.

In Slovakia export, real effective exchange rate, interest rate and inflation impulses have decelerated the NPL ratio; savings have slightly accelerated the NPL ratio in the time period of 36-month; the NPL response on investment has been decelerating; and the GDP growth has accelerated the NPL ratio in the time period of 24 to 36-month.

In Slovenia investment activity and inflation have decelerated the NPL ratio; meanwhile export, real effective exchange rate and GDP have slightly decelerated the NPL ratio; the responses of the NPL ratio on interest rate and savings have been accelerating in the observed time period (Table 7).

The results are suggesting that appreciation has decelerated the NPL ratio in Slovakia, Slovenia and the Czech Republic. The GDP growth might improve borrowers' ability to serve their bank loans in Slovenia, meanwhile the accelerating NPL ratio dynamics has failed to support the hypothesis that the GDP growth fosters an improvement in the NPL ratio in the case of Slovakia. Deceleration in the NPL on export impulses has supported the pro-cyclical theory in Slovakia, Slovenia and the Czech Republic. The insignificant autoregressive NPL response probably indicates low level of the NPL ratio exogeneity. Real interest rate impulses have caused acceleration in the NPL ratio in Slovenia. The response of NPL on inflation has supported the hypothesis about lowering inflation that has decelerated the NPL ratio in Slovakia, Slovenia and the Czech Republic. We have proved insignificant pro-cyclicality due to decelerating response of the NPL ratio on equity prices that does provide a tentative explanation of 
business and financial procyclicality in the Czech Republic. Savings have deteriorated the NPL ratio in the case of Slovenia and Slovakia.

Table 8

\section{Supported Hypothesis}

\begin{tabular}{|c|c|c|}
\hline Hypothesis & Explained hypothesis & $\begin{array}{l}\text { supported } \\
\text { hypothesis } \\
\text { CZ S SLO }\end{array}$ \\
\hline $\begin{array}{l}\text { Appreciation growth } \\
\text { accelerates NPL growth }\end{array}$ & $\begin{array}{l}\text { Appreciation could cause deceleration in export and GDP } \\
\text { growth due to lower competitiveness of domestic economy. } \\
\text { The loan portfolio quality deteriorates due to high share of } \\
\text { loans nominated in foreign currency if domestic currency } \\
\text { depreciates. }\end{array}$ & no no no \\
\hline $\begin{array}{l}\text { GDP growth decelerates } \\
\text { NPL growth }\end{array}$ & Theory of financial and real sector procyclicality. & - no yes \\
\hline $\begin{array}{l}\text { Rising unemployment } \\
\text { decelerates NPL growth }\end{array}$ & $\begin{array}{l}\text { Expected unemployment growth rationally decreases } \\
\text { demand for loans and rising unemployment improves loan } \\
\text { portfolio quality. }\end{array}$ & yes - \\
\hline $\begin{array}{l}\text { NPL is exogenous } \\
\text { variable }\end{array}$ & NPL is autoregressive process. & no no no \\
\hline $\begin{array}{l}\text { Export growth } \\
\text { decelerates NPL growth }\end{array}$ & Theory of financial and real sector procyclicality. & yes yes yes \\
\hline $\begin{array}{l}\text { Rising interest rates } \\
\text { accelerate NPL growth }\end{array}$ & $\begin{array}{l}\text { Financial liberalization contributes to financing risky } \\
\text { projects and interest rates are higher. } \\
\text { Higher interest rates attract speculative capital flows which } \\
\text { can deteriorate loan portfolio quality. }\end{array}$ & no no yes \\
\hline $\begin{array}{l}\text { Lowering inflation } \\
\text { decelerates NPL growth }\end{array}$ & Higher inflation makes macro environment less transparent. & yes yes yes \\
\hline $\begin{array}{l}\text { Rising investment } \\
\text { activity accelerates NPL } \\
\text { growth }\end{array}$ & $\begin{array}{l}\text { Soft loan policies mitigate market cleaning and } \\
\text { restructuring of domestic capacities; loan portfolio quality } \\
\text { deteriorates if investment activity is counterproductive. }\end{array}$ & no no no \\
\hline $\begin{array}{l}\text { Higher prices of equity } \\
\text { decelerate NPL growth }\end{array}$ & $\begin{array}{l}\text { Higher prices of equity increase investment activity and } \\
\text { GDP growth due to higher value of potential collaterals } \\
\text { eligible for credit assurance. }\end{array}$ & $-\quad-$ \\
\hline $\begin{array}{l}\text { Increasing savings } \\
\text { decelerate NPL growth }\end{array}$ & Ample liquidity could deteriorate NPL ratio. & - no no \\
\hline
\end{tabular}

Symbols: CZ: the Czech Republic, S: Slovakia, SLO: Slovenia.

Source: Own calculations (March 2007).

We proved the hypothesis that growth in the amount of available finance and ample liquidity of the banking sector might harm banking performance probably due to soft budget constraints in the case of Slovakia and Slovenia. The impact of GDP growth on the NPL ratio is usually represented as procyclical and we proved for Slovenia the procyclicality of GDP growth and banking sector performance in the sense of decelerating NPL ratio. Export has decelerated the NPL ratio in Slovakia, Slovenia and the Czech Republic. Rising unemployment has limited demand for loans due to the negative expectations of households and it has decelerated the NPL ratio in the case of 
the Czech Republic. Appreciation of real exchange rate could contribute to the build-up in the crisis through shifts in international competitiveness coupled with terms of trade deterioration due to general rise in the productivity rate. The following limited growth prospects in export-oriented industries could ultimately lead to economic contraction with direct implications on loans performance at the fact that that bank lending surveys show that loans granted to enterprises are partly hedged by their export proceeds. We have proved the opposite that appreciation has decelerated the NPL ratio in Slovakia, Slovenia and the Czech Republic. An increase in investment activity could deteriorate the NPL ratio probably due to soft budget constraints or counterproductive investment but this was not proved for any of the economies.

\section{Conclusion}

The macroeconomic stability reduces the systemic risk and plays a role in influencing the non-performing loans ratio. The banks' behaviour is usually procyclical and reinforces the current development of the business cycle.

The slowdown in economic activity could be expected to deteriorate the non-performing loans ratio in Slovenia. Increasingly diversified export and import structures have obviously reduced the vulnerability to terms of trade deterioration and export growth has improved the non-performing loans ratio in the Czech Republic, Slovakia and Slovenia. An excessive real exchange rate appreciation could potentially erode competitiveness and could result in deterioration in exporters' performance as banks clients, with possible negative repercussion on debt repayments, which was not proved for any of the analysed economies. Savings have accelerated the non-performing loans ratio in the case of Slovakia and Slovenia probably due to the mentioned ample liquidity of the banking sectors. Volatility of inflation is accompanied by more uncertainty about future price development and given that inflation has been falling throughout the region in line with monetary convergence with EU, inflation movements have decelerated the non-performing loans ratio in the Czech Republic, Slovakia and Slovenia. The effort to fight stubborn inflation has often led to the high real interest rates that have deteriorated the non-performing loans ratio in Slovenia.

\section{References}

Arpa, M., Giulini, I., Ittner, A., Pauer, F. (2001), "The Influence of Macroeconomic Developments on Austrian Banks: Implications for Banking Supervision”. Basel, Bank for International Settlements, BIS Paper No. 1, http://www.bis.org/publ/bispap01c.pdf.

Babouček, I., Jančar, M. (2005), "A VAR Analysis of the Effects to Macroeconomic Shocks to the Quality of the Aggregate Loan Portfolio of the Czech Banking Sector". Prague, Czech National Bank, Working Paper Series 1.

Bárta, V., Singer, M. (2006), "The Banking Sector after 15 Years of Restructuring: Czech Experience and Lessons". Basel, BIS Paper No. 28, http://www.bis.org/publ/bppdf/bispap28k.pdf.

Berglöf, E., Roland, G. (1995), "Bank Restructuring and Soft Budget Constraints in Financial Transition". CEPR, Discussion Paper No. 1250, http://ideas.repec.org/p/cpr/ceprdp/1250.html.

Blaschke, W., Jones, M. (2001), "Stress Testing of Financial Systems: An Overview of Issues, Methodologies and FSAP Experiences". Washington, DC, IMF Working Paper No. 01/88), http://www.imf.org/external/pubs/ft/wp/2001/wp0188.pdf.

Borio, C., Lowe, P. (2002), "Asset Prices, Financial and Monetary Stability: Exploring the Nexus". Bank for International Settlements, BIS Working Papers No. 114, July, pp. 3-45. 
Borio, C., Furfine, C., Lowe, P. (2001), "Procyclicality of the Financial System and Financial Stability: Issues and Policy Options". In Marrying the Macro and Micro-Prudential Dimension of Financial Stability. Bank for International Settlements, BIS Paper No. 1, March, pp. 24-31, http.//www.bis.org.

Box, G. E. P., Jenkins, G. M. (1976), Time Series Analysis. Forecasting and Control. San Francisco : Holden-Day.

Brandmeier, M. (2006), "Reasons for Real Appreciation in Central Europe". Centre for Globalisation and Europeanization of the Economy, Discussion Paper No. 55, May, pp. 396-400, http://www.cege.wiso.uni-goettingen.de/Dokumente/55_Brandmeier.pdf.

Breuss, F., Fink, G., Haiss, P. (2004), "How Well Prepared Are the New Member States for the European Monetary Union?" Europe Institute at the Vienna University of Economics and Business Administration and Bank Austria Creditanstalt Paper for the Special Issue Journal of Policy Modeling: Salvatore, D. (ed.), "Enlargement of the European Monetary Union", http://www.wifo.ac.at/Fritz.Breuss/Breuss_Fink_Haiss_JPM2004.PDF.

Brzoza-Brzezina, M. (2005), "Lending Booms in the New Member States, Will Euro Adoption Matter?" ECB Working Paper No. 543, December, http://www.ecb.int/pub/pdf/scpwps/ecbwp543.pdf.

Calvo, G. A., Mendoza, E. (2000), "Contagion, Globalization and the Volatility of Capital Flows", in Edwards, S., ed., Capital Flows and the Emerging Economies. Chicago: University of Chicago Press, pp. 12-43.

Canova, F. (2003), Methods for Applied Research 6: VAR Models. Rome and London: Universitat Pompeu Fabra, London Business School and CEPR. http://www.ifk-cfs.de/papers/Canova Chapter 6.pdf).

Dickey, D. A., Fuller, W. A. (1979), "Distribution of the Estimators for Autoregressive Time Series with Unit Root". Journal of American Statistical Association 74, pp. 427-431.

Engle, R. F., Granger, C. W. J. (1978), "Co-Integration and Error Correction Representation Estimation and Testing". Econometrica, 46 (2), pp. 251-276.

ECB (2006), "Acceding Economies Macro Environment and Banking Sector". European Central Bank Occasional Paper No. 48, July, pp. 11-31, http://www.ecb.int/ecbop48[1].pdf.

Edwards, S. (2001), Exchange Rate Regime, Capital Flows and Crisis Prevention. Los Angeles: NBER and University of California, http://www.anderson.ucla.edu/faculty/sebastian.edwards/ woodstock2.pdf.

Eichengreen, B., Mussa, M., Milesi-Ferretti, M. G., Detragiace, E. (1999), "Liberalizing Capital Movements: Some Analytical Issues". Washington, DC, IMF Paper No. 17, http://www.imf.org/ external/pubs/ft/issues/issues17/index.htm.

English, W. (1996), "Inflation and Financial Sector Size". Federal Reserve Board, Finance and Economics, Discussion Paper Series, No. 16, pp. 5-49, http://www.federalreserve.gov/PUBS/ feds/1996/199616/199616pap.pdf.

EU Monitor (2006), Deutsche Bank Research, May, pp. 1-11, http://www.dbresearch.com/ PROD/DBR_INTERNET_EN-PROD/PROD0000000000198571.pdf.

European Commission (2006), Convergence Report. Brussels: European Commission, Directorate General for Economic and Financial Affairs, Spring Forecast, http://europa.eu.int/scadplus/leg/ en/lvb/l25057.htm.

Festić, M. (2007), "Makro dejavniki rezultatov bančnega sektorja (Macro Determinants of the Banking Sector Results in Slovenia and Slovakia)". Bančni vestnik, 56, September, pp. 24-30.

Golin, J. (2005), The Bank Credit Analysis Handbook, a Guide for Analysts, Bankers and Investors. London: Wiley Finance.

Greene, W. H. (2003), Econometric Analysis, 5th ed. New Jersey: New York University, Prentice Hall, pp. $145-152$.

Havlik, P. (2003), "EU Enlargement: Implications for Growth and Competitiveness". The Vienna Institute for International Economic Studies, a study commissioned by the Austrian Federal Ministry for Economy and Labour. http://www.bmwa.gv.at/NR/rdonlyres/A21B2A97-173C-4CC2-93B4F3293339B56A/8871/WIIWStudie2003.pdf.

International Monetary Fund (2006), Global Financial Stability Report - Statistical Appendix. Washington, DC: IMF, http://www.imf.org/external/ns/search.aspx?NewQuery=RoA\&Sort= Score\&Filter_Val=N\&page $=2 \&$ col=SITENG $\&$ collection $=\&$ year $=\&$ rcount $=50 \&$ swr $=0 \&$ LastQuery $=\&$ Lan $=e n g \& a d v=0$.

Kaminsky, G., Reinhart, C. M. (1999), "The Twin Crises: the Causes of Banking and Balance of Payments Problems". American Economic Review, 89, pp. 473-500. 
Kavkler, A., Böhm, B. (2006), "Using canonical correlations in testing for common nonlinear com-ponents". Methodological working paper (printed edition), 3 (1), pp.75-88. http://mrvar.fdv.uni-lj.si/pub/mz/mz3.1/kavkler.pdf [downloaded: November 19, 2007].

Lardy, N. R. (1999), "When Will China's Financial System Meet China's Needs?" Stanford, CA, Stanford University, Center for Research on Economic Development and Policy Reform, Paper prepared for Conference on Policy Reform in China, November, http://www.brookings.org/views/ papers/lardy/19991118.htm.

Pesaran, H. H., Shin, Y. (1998), "Generalised Impulse Response Analysis in Linear Multivariate Models". Economics Letters, 58, pp. 17-29.

Quagliariello, M. (2003), Macroeconomics Indicators Useful in Predicting Bank Loan Quality? Evidence from Italy. Rome: Bank of Italy, http://www-users.york.ac.uk/ mq1 02/mpa_en.pdf.

Rajan, R. G. (2005), "Has Financial Development Made the World Riskier?" Paper presented at the Jackson Hole Conference, August, http://neweconomist.blogs.com/new_economist/ 2005/papers_from_the-html.

Shu, Chan (2002), "The Impact of Macroeconomic Environment on the Asset Quality of Hong Kong's Banking Sector". Hong Kong Monetary Authority Research Memorandum, December, http://www.info.gov.hk/hkma/eng/research/index.htm.

Sims, Ch. A., Zha, Tao (1999), "Error Band for Impulse Responses". Econometrica, 67 (5), pp. 1113-1156, http://ideas.repec.org/a/ecm/emetrp/v67y1999i5p1113-1156.html.

National Bank of Slovakia (2004), "Analysis of the Slovak Banking Sector 2004", http://www.nbs. sk/DFT/PUBLIK/ANALYZA/2004/2004A.PDF.

Thursby, J. G. (1982), "Misspecification, Heteroscedasticity, and the Chow and Goldfeld-Quandt Tests". The Review of Economics and Statistics, 64 (2), pp. 314-321.

Wall, M. E., Rechtsteiner, A., Rocha, L. M. Luis (2003), "Singular Value Decomposition and Principal Component Analysis", in Practical Approach to Microarray Data Analysis. Norwell, MA: Kluwer, pp. 22-24, http://public.lanl.gov/mewall/kluwer2002.html.

\section{Key to Symbols}

AIC = Akaike info criterion

$A R, M A=$ autoregressive process, moving average process

ARCH, LM = Residuals Test for ARMA models

DW = Durbin Watson Statistik

EXCHR = exchange rate

EXP $=$ export

$\mathrm{FDI}=$ foreign direct investment

GDP = gross domestic product

$\mathrm{HCPI}=$ harmonized consumer price index

INTR3M = short run (real) interest rate

INTRLR = long run (real) lending interest rate

INVEST = gross investment as \% of GDP

$\mathrm{NPL}=$ non-performing loans as share of total loans (in \%)

$\mathrm{PDEBT}=$ public debt

$\mathrm{R}^{2}=$ Coefficient of Determination

REFFEXCHR = real effective exchange rate

S.E. $=$ S.E. of regression

SAVINGS $=$ gross savings as $\%$ of GDP

SHARES = stock exchange index

SSR = Sum squared resid

St. Dev $=$ standard deviation

UNEMPLOY = unemployment

VAR = variance decomposition method

$\rho=$ probability value 


\section{Appendix}

Figure 1

Estimated Function for Slovenia

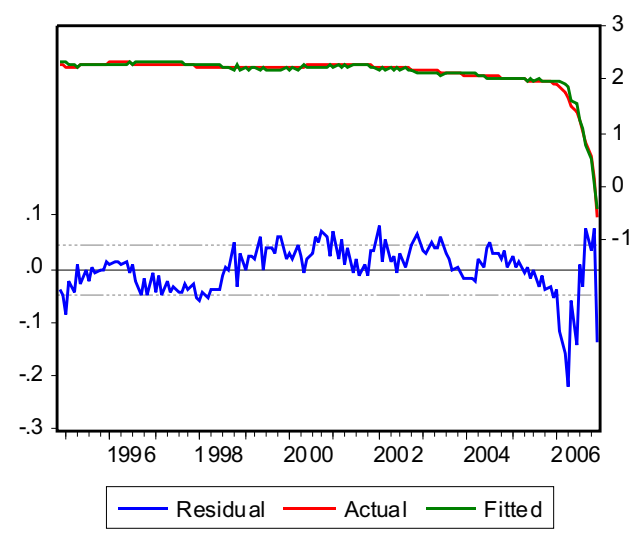

Figure 2

Estimated Function for Slovakia

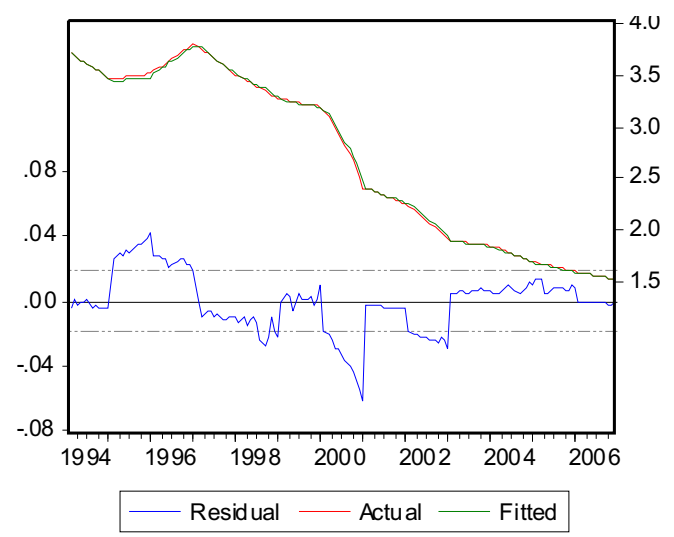

Figure 3

Estimated Function for the Czech Republic

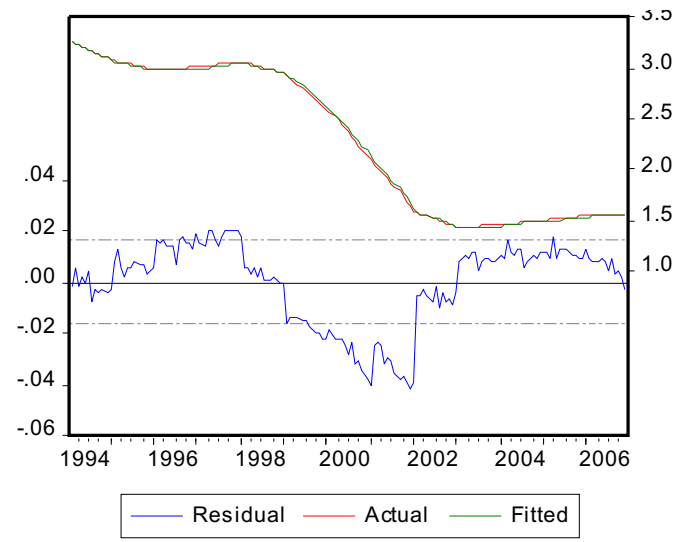


Table A

Correlation Matrix

\begin{tabular}{|c|c|c|c|c|c|c|c|c|c|c|c|c|c|}
\hline $\begin{array}{c}\text { Czech } \\
\text { Republic }\end{array}$ & EXCHR & GDP & HCPI I & INTR3M & INVEST & EXP & NPL & PDEBT & \begin{tabular}{|c|} 
REFFEX \\
CHR
\end{tabular} & \begin{tabular}{|c|} 
SA- \\
VINGS
\end{tabular} & $\begin{array}{l}\text { SHA- } \\
\text { RES }\end{array}$ & \begin{tabular}{|c|} 
UNEM- \\
PLOY \\
\end{tabular} & \begin{tabular}{|c|} 
INTR- \\
LR
\end{tabular} \\
\hline EXCHR & 1 & 0.1091 & -0.6381 & -0.7394 & -0.0969 & -0.0275 & -0.8007 & 0.4297 & 0.9369 & -0.7199 & 0.3463 & 0.0942 & -0.7594 \\
\hline GDP & 0.1091 & 1 & -0.1184 & -0.3908 & 0.4831 & 0.3515 & -0.2287 & -0.0160 & 0.1466 & 0.1786 & 0.1106 & -0.0030 & 0.0268 \\
\hline HCPI & -0.6381 & -0.1184 & 1 & .8795 & -0.3147 & -0.3836 & 0.8342 & -0.7012 & -0.7859 & 0.6549 & -0.3956 & -0.6216 & 0.8544 \\
\hline INTR3M & -0.7394 & -0.3908 & 0.8795 & 1 & -0.3723 & -0.4151 & 0.9326 & -0.6617 & -0.8479 & 0.5815 & -0.4244 & -0.5180 & 0.8523 \\
\hline INVEST & -0.0969 & 0.4831 & -0.3147 & -0.3723 & 1 & 0.8740 & -0.3195 & 0.2575 & 0.1441 & 0.3134 & 0.1715 & 0.6771 & -0.2369 \\
\hline EXP & -0.0275 & 0.3515 & -0.3836 & -0.4151 & 0.8740 & 1 . & 86 & 0.3117 & 0.1920 & 0.2719 & 0.2288 & 0.7731 & -0.3345 \\
\hline NPL & -0.8007 & -0.2287 & 0.8342 & 0.9326 & -0.3195 & -0.3886 & 1 & -0.7107 & -0.9076 & 0.6195 & -0.3903 & -0.5211 & 0.9373 \\
\hline PDEBT & 0.4297 & -0.0160 & 012 & -0.6617 & 0.2575 & 117 & -0.7107 & 1 & 0.5741 & -0.5616 & 0.3059 & 0.4575 & -0.7054 \\
\hline REFFEXCHR & 0.9369 & 0.1466 & -0.7859 & 79 & 441 & 920 & -0.9076 & 0.5741 & 1 & -0.7080 & 0.4100 & 0.3297 & -0.8842 \\
\hline SAV & -0.7199 & 1786 & 6549 & .5815 & 3134 & 2719 & 0.6195 & -0.5616 & -0.7080 & 1 & -0.1624 & 0.0470 & 0.6773 \\
\hline SHARES & 0.3463 & 0.1106 & -0.3956 & -0.4244 & 0.1715 & 0.2288 & -0.3903 & 0.3059 & 0.4100 & -0.1624 & 1 & 0.3980 & -0.4221 \\
\hline UNEMPLOY & 0.0942 & -0.0030 & -0.6216 & -0.5180 & 0.6771 & 0.7731 & -0.5211 & 0.4575 & 0.3297 & 0.0470 & 0.3980 & 1 & -0.5875 \\
\hline INTRLR & -0.7594 & 0.0268 & 0.8544 & 0.8523 & -0.2369 & -0.3345 & 0.9373 & -0.7054 & -0.8842 & 0.6773 & -0.4221 & -0.5875 & 1 \\
\hline
\end{tabular}

\begin{tabular}{|c|c|c|c|c|c|c|c|c|c|c|c|c|c|}
\hline Slov: & EXCHR & GDP & CPI & II & INVEST & EXP & NPL & PDEBT & $\begin{array}{c}\text { REFFEX } \\
\text { CHR }\end{array}$ & \begin{tabular}{|c|} 
SA- \\
VINGS
\end{tabular} & $\begin{array}{l}\text { SHA- } \\
\text { RES }\end{array}$ & \begin{tabular}{|c|} 
UNEM- \\
PLOY \\
\end{tabular} & \begin{tabular}{|c|}
$\begin{array}{c}\text { INTR- } \\
\text { LR }\end{array}$ \\
\end{tabular} \\
\hline & 1 & 970 & & & & 50 & & & 02 & 47 & 45 & 34 & $-c$ \\
\hline GDP & 70 & 1 & 38 & - & 58 & 577 & 0.2356 & 171 & 0.0710 & 5391 & .2008 & -0.0697 & 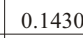 \\
\hline $\mathrm{CPI}$ & & 38 & 1 & 669 & & 1344 & 53 & 553 & 54 & 6326 & 83 & 74 & 0.7774 \\
\hline & & 27 & & & & 154 & 47 & 585 & 315 & 12 & 34 & -0. & - \\
\hline & & 0358 & 721 & 570 & 1 & 7953 & & 0.5551 & 0.0636 & 2861 & -0.3417 & .6575 & -0.2162 \\
\hline 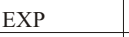 & 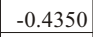 & (1) & 44 & $4=$ & & 1 & - & 0.4628 & $0.17 \times 10$ & .5762 & -0.3580 & 0.6268 & 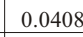 \\
\hline DI & 297 & 356 & 7353 & 7347 & -0.3154 & -0.0684 & 1 & -0.4055 & -0.8235 & 5739 & -0.2915 & -0.4444 & 0.9604 \\
\hline DT & 4 & 1 & 3 & -0.0585 & 1 & 8 & & 1 & 31 & 99 & 2 & 45 & . \\
\hline & & & & & & -0 & & & 1 & 65 & & 49 & -0.8438 \\
\hline & & & & & & & & .1709 & 5 & 1 & 4129 & .3400 & 0 \\
\hline & & 08 & 83 & -0 & 417 & -0.3580 & -0.2915 & -0.3182 & 0.6776 & -0.4129 & 1 & 11 & -0.3867 \\
\hline EMPLOY & -0.4954 & -0.0697 & .0274 & & 06575 & 0.6268 & -0.4444 & م & 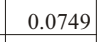 & 0.3400 & -0. & 1 & -0.2 \\
\hline TRLR & -0.0497 & 430 & 774 & 7578 & -0.2162 & 0.0408 & 0.9604 & -0.2316 & -0.8438 & 0.6363 & -0.3867 & -0.2749 & \\
\hline
\end{tabular}

\begin{tabular}{|l|r|r|r|r|r|r|r|r|r|r|r|r|r|}
\hline \multicolumn{1}{|c|}{ Slovenia } & EXCHR & GDP & HCPI & INTR3M & INVEST & EXP & NPL & PDEBT & $\begin{array}{c}\text { REFFEX } \\
\text {-CHR }\end{array}$ & $\begin{array}{c}\text { SA- } \\
\text { VINGS }\end{array}$ & $\begin{array}{c}\text { SHA- } \\
\text { RES }\end{array}$ & $\begin{array}{c}\text { UNEM- } \\
\text { PLOY }\end{array}$ & $\begin{array}{c}\text { INTR- } \\
\text { LR }\end{array}$ \\
\hline EXCHR & 1 & 0.6181 & 0.8659 & 0.9067 & -0.6555 & 0.0648 & 0.5786 & -0.2254 & -0.1521 & -0.0749 & -0.7954 & 0.0813 & 0.6417 \\
\hline GDP & 0.6181 & 1 & 0.4166 & 0.4461 & -0.3898 & 0.4014 & 0.6203 & 0.1332 & -0.2930 & 0.5006 & -0.3565 & 0.4100 & 0.2106 \\
\hline HCPI & 0.8659 & 0.4166 & 1 & 0.8170 & -0.6181 & 0.1909 & 0.5528 & -0.0135 & 0.1232 & 0.0200 & -0.6203 & -0.0470 & 0.6493 \\
\hline INTR3M & 0.9067 & 0.4461 & 0.8170 & 1 & -0.7338 & 0.1392 & 0.7299 & -0.1431 & -0.2466 & 0.0003 & -0.8836 & 0.2435 & 0.7537 \\
\hline INVEST & -0.6555 & -0.3898 & -0.6181 & -0.7338 & 1 & -0.1261 & -0.6094 & 0.0983 & 0.3561 & -0.0475 & 0.7159 & -0.1928 & -0.5856 \\
\hline EXP & 0.0648 & 0.4014 & 0.1909 & 0.1392 & -0.1261 & 1 & 0.5967 & 0.5610 & 0.0995 & 0.7035 & 0.0044 & 0.4360 & 0.0849 \\
\hline NPL & 0.5786 & 0.6203 & 0.5528 & 0.7299 & -0.6094 & 0.5967 & 1 & 0.3748 & -0.3168 & 0.6111 & -0.6073 & 0.6341 & 0.5872 \\
\hline PDEBT & -0.2254 & 0.1332 & -0.0135 & -0.1431 & 0.0983 & 0.5610 & 0.3748 & 1 & 0.1188 & 0.7125 & 0.2802 & 0.3775 & 0.0257 \\
\hline REFFEXCHR & -0.1521 & -0.2930 & 0.1232 & -0.2466 & 0.3561 & 0.0995 & -0.3168 & 0.1188 & 1 & -0.0429 & 0.4372 & -0.4117 & -0.0639 \\
\hline SAVINGS & -0.0749 & 0.5006 & 0.0200 & 0.0003 & -0.0475 & 0.7035 & 0.6111 & 0.7125 & -0.0429 & 1 & 0.2041 & 0.5878 & 0.0640 \\
\hline SHARES & -0.7954 & -0.3565 & -0.6203 & -0.8836 & 0.7159 & 0.0044 & -0.6073 & 0.2802 & 0.4372 & 0.2041 & 1 & -0.2057 & -0.6084 \\
\hline UNEMPLOY & 0.0813 & 0.4100 & -0.0470 & 0.2435 & -0.1928 & 0.4360 & 0.6341 & 0.3775 & -0.4117 & 0.5878 & -0.2057 & 1 & 0.2028 \\
\hline INTRLR & 0.6417 & 0.2106 & 0.6493 & 0.7537 & -0.5856 & 0.0849 & 0.5872 & 0.0257 & -0.0639 & 0.0640 & -0.6084 & 0.2028 & 1 \\
\hline
\end{tabular}

